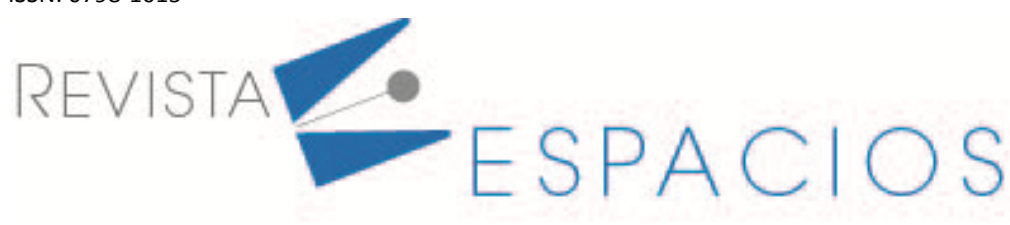

Vol. 41 (45) $2020 \cdot$ Art. 8

Recibido/Received:25/06/2020 • Aprobado/Approved: 14/08/2020 • Publicado/Published: 26/11/2020

\title{
State and directions of development of land cadastral practice
}

\section{Estado y direcciones del desarrollo de la práctica catastral de la tierra}

\author{
BRYZHKO, Viktor G. ${ }^{1}$ \\ BRYZHKO, llya V. ${ }^{2}$
}

\begin{abstract}
Land serves as the basis for the development of any economic systems and objects. Land property management is important for all economic entities. Effective management of land and property complexes depends on the availability of reliable and objective information about the land. The purpose of land cadastral practice is the collection, systematization, presentation and use of such information. The purpose of this work is to substantiate the author's proposals for improving the land cadastral practice in Russia. To achieve this goal, the authors solve the following tasks: assessing the Russian land cadastre practice, identifying the main shortcomings of land cadastral activities, substantiating proposals for the development of land cadastral practice, determining the most urgent tasks of improving the land cadastral practice.

key words: land cadastral practice, land accounting, cadastral valuation of land, soil appraisal, cadastre development

\section{Resumen}

La tierra sirve como base para el desarrollo de cualquier sistema y objeto económico. La administración de tierras es importante para todas las entidades económicas. El manejo efectivo de los complejos de tierra y propiedad depende de la disponibilidad de información confiable y objetiva sobre la tierra. El propósito de la práctica catastral de la tierra es la recolección, sistematización, presentación y uso de dicha información.

El objetivo de este trabajo es fundamentar las propuestas del autor para mejorar la práctica catastral de la tierra en Rusia. Para lograr este objetivo, los autores resuelven las siguientes tareas: evaluar la práctica del catastro de la tierra rusa, identificar las principales deficiencias de las actividades catastrales de la tierra, justificar propuestas para el desarrollo de la práctica catastral de la tierra, determinar las tareas más urgentes de mejorar la práctica catastral de la tierra.

Palabras clave: práctica catastral de la tierra, contabilidad de la tierra, valoración catastral de la tierra, evaluación del suelo, desarrollo del catastro
\end{abstract}

\section{Introduction}

Land serves as the basis for the formation and development of any property complex. Land is an independent and special property. Without land, it is impossible to operate any real estate inextricably linked to it. The specific characteristics of land property determine special approaches to the accounting and assessment of land in the process of human life and in the organization of production processes.

\footnotetext{
${ }^{1}$ Doctor of Economic Sciences, Professor, Land management department, Perm State Agro-Technological University named after Academician D.N. Pryanishnikov; Perm; Russian Federation, E-mail: bryzhko@bk.ru

${ }^{2}$ Candidate of Economic Sciences, Associate Professor, Cartography and geoinformatics department, Perm State University; Perm; Russian Federation, Email: zemproekt@yandex.ru
} 
In the process of economic activity, for the effective management of property complexes, it is important to have objective information about the location of land plots with respect to logistics centers and infrastructure facilities. Information on the size of land masses, the configuration and location of the boundaries of property complexes, the quality of the land, the value of land property and other real estate items are important. Landowners also evaluate the liquidity of property complexes and the investment attractiveness of real estate. This information is of interest to land owners, land users, and land tenants. These data are taken into account in the process of production management, production processes and property management.

The listed information constitutes a certain totality of information on the qualitative and quantitative characteristics of land property complexes. This set of information about the land forms the data of the land cadastre (real estate registry). The cadastral system of land and other property affects the state of individual sectors of economic activity and the economy as a whole. In addition to the informational basis for organizing the rational use of land and other resources, the cadastre serves as an instrument of the fiscal policy of the state. The cadastre of land property should be considered an element of regulation of land and property relations in society.

Cadastral indicators affect the development of the land use system, market processes in land use, the development of urban spatial infrastructure (Chengri Ding, Xingshuo Zhao, 2014, 83-90). The development of the institution of land ownership depends on the state of the land cadastre, which determines the social and economic situation of economic entities in society, stimulates the growth of investments, improves financing of production processes (Deininger K., Feder G., 2001, 287-331). This provision is true for agriculture, industry, other sectors of the economy, entrepreneurship, and market processes.

The cadastre of land resources is always carried out in the interests of social groups possessing power in the state. This is an instrument of the state mechanism for managing land property. Depending on the economic interests of the ruling elites, the composition and content of land and cadastral works differ. At the same time, the main purpose of cadastral activity under any government remains to restore order in the field of land use and to ensure the stable receipt of taxes for the use of land property in the budget.

In the Russian land cadastre, the most radical changes have occurred over the past thirty years, these changes are associated with the reform of the land management system. Fundamental changes in land cadastral work are due to a change in socio-economic formations in the Russian state at the end of the last century.

The old domestic cadastral system included in its structure: registration of land use with the issuance of state acts on land; accounting for the quantity and quality of land in a single reporting form for the whole country; land valuation, including economic valuation (public and private) and soil appraisal. The whole system of land cadastre in pre-reform times was focused on the idea of land as a place of production and settlement of people, a natural resource, the main means of agricultural production (Galchenko S.A., 2017, 5-12). This explains the fact that land appraisal work was carried out mainly on agricultural land.

The modern Russian system of land cadastral activity puts the function of land as an object of real estate, an object of commodity-money relations, at the forefront. Today, land is the backbone of the real estate market. Accordingly, the fiscal function of the land cadastral activity also came to the fore. The land cadastre includes: registration of rights to real estate and transactions with it; registration of land and other real estate objects (formation and maintenance of a unified state register of real estate); cadastral valuation of land, the result of which is to obtain indicators of the cadastral value of land property (Galchenko S.A., 2017, 5-12).

As a result of radical transformations of the land cadastral practice, many years of proven useful approaches, techniques and actions in the field of the land cadastre were lost. The useful experience of past years turned out to be unclaimed and is not taken into account in the practice of maintaining the land cadastre. New 
methodological approaches, practical actions and techniques are formed in isolation from historical experience, the achievements of domestic science and the practice of maintaining the land cadastre.

This led to the loss of the connection of land cadastral practice with other functions of land management functions, as a special type of real estate, the presence of many contradictions in land cadastral practice, and a decrease in the effectiveness of land cadastral activities. This requires addressing the shortcomings of the practice of land cadastre and the development of land cadastral activities based on new scientific and methodological approaches.

The aim of this work is to substantiate the author's proposals for improving the domestic land cadastral practice.

Achieving this goal requires a consistent solution of the following tasks: assessing the modern land cadastre practice, identifying the main shortcomings of land cadastral activities, substantiating proposals for the development of land cadastral practice, determining the most urgent tasks of improving the land cadastral practice.

\section{Methodology}

The complex nature of the research performed is ensured by the fact that in the process of work various research methods were used. A detailed review of the legal framework, reports and statistics was carried out. An analysis of publications on the research topic was carried out, consultations were held with leading authors, foreign experience was taken into account and up-to-date information was obtained on the current situation with land ownership in Russia and on approaches to effectively solving this problem.

\section{Results}

The effectiveness of the modern system of land cadastre in the country is low, due to the presence of a large number of shortcomings of land cadastral practice. We consider the most characteristic contradictions of the system and the shortcomings of practical activity in more detail.

The development of the institution of land ownership is restrained by the low pace of work on the delineation of ownership in the country. This problem is especially acute in relation to agricultural land. Here, the delineation of land by ownership and owners with fixing the boundaries of land use is made only on $40 \%$ of the land. Moreover, no more than $20 \%$ of land plots that have exact areas and borders are used for cadastral registration and are used in the agricultural sector (Khlystun V.N., 2018, 11-18).

If we take into account that $96 \%$ of private property lands in the country are represented by agricultural lands, then the extent of the problem becomes clear. The proportion of agricultural land for functional purposes in the country is $22.3 \%$ of the total land fund, and their area exceeds 382.5 million ha (Rosreestr, 2019, 198). Of this area, only on the territory of 153 million hectares there are no problems with owners and forms of ownership. For the remaining 229.5 million hectares, the problems of demarcation and belonging to specific entities remain relevant.

Imperfection of land cadastral practice is manifested at all stages of production activity and is manifested in the formation of land property complexes, registration and accounting of land property, and land and appraisal work. Deficiencies in land valuation lead to such a serious problem as contesting the cadastral value of land. In 2018, 29,531 applications were submitted in the country to contest the cadastral value of 49,496 plots. The decision to reduce the cadastral value in favor of land owners was made on 17,720 applications, which is $60 \%$ of all applications. At the same time, the amount of cadastral value of land after contesting the results of the assessment decreased by $18 \%$ (Rosreestr, 2019, 198). 
The ongoing negative processes are explained by the imperfection of the land cadastral practice and the shortcomings in the system of distribution of powers in the management of cadastral activities. Deficiencies appear in all the constituent parts of the land cadastre and require elimination in the process of registration, accounting, assessment of land property complexes.

Meanwhile, the need to comply with the principle of a holistic complete consistent description of real estate in the process of cadastral activity has not been canceled. At the same time, the tasks of developing the registration, accounting and evaluation of cadastral systems should coincide (Ivanov N.N., 2019, 42-47).

The basis of the problems of modern land cadastral practice is the initiating nature of the implementation of the main types of cadastral activities. This is the declarative nature of land registration and land use registration. Accounting and registration are closely related, interdependent, and in practice are carried out simultaneously. The declarative nature of these components of the cadastre leads to failures in the cadastral information system, loss of stability of the existing land use system, and a low level of protection of legal rights to land property.

The land cadastre is maintained in the interests of the whole society and the state. In this regard, the procedure for starting land cadastral works after the appeal of potential land users to the cadastral authorities seems doubtful. This leads to loss of budget revenues at different levels and controllability of land property.

Our concept of improving land cadastral practice is based on the thesis that it is necessary to bring the essence, purpose and objectives of the cadastre into line with the regulations and procedures for maintaining it. If the land cadastre is maintained in the interests of the state, then land registration and registration should be carried out at the initiative of state (or municipal) authorities in accordance with their legal authority in this area. Then cadastral actions should be universal, not declarative.

Basic measures for the development of land cadastral practices based on changes in the initiating nature of cadastral activities are justified in table 1.

The improvement of existing practice should be promoted by the introduction of a universal (rather than declarative) procedure for cadastral registration of land and registration of real estate on the initiative of state or municipal authorities, depending on the distribution of management functions in the field of real estate. To overcome the problems in the field of cadastral valuation of land, we consider it appropriate to coordinate the results of the assessment with interested municipalities, which will help to avoid further numerous disputes between the estimated indicators (the value of the cadastral value of land). For a more objective assessment of land as a means of production, soil appraisal is necessary. It should be carried out at the initiative of public authorities in all lands with fertility.

These are lands intended for agriculture and lands directly used in agricultural production. These proposals are aimed at the development of land cadastral practice in the country.

In national economic systems, efficiently organized land cadastral activity is important because it allows providing economic development with modern and reliable information about the state of land and property complexes, the structure of the land balance, the economic potential of the land, the possibilities for the potential development of industrial and territorial complexes, and the social prospects for administrative territorial entities.

Land cadastral activity serves the purpose of ensuring priority state management tasks, creates the information basis for the rational organization of land use, provides information for the implementation of fiscal state and municipal policies. Therefore, the state of the land cadastre is traditionally given a lot of attention in the management system, and in production, and in scientific research. 
Table 1

Proposals for the development

of land cadastral practice

\begin{tabular}{|l|l|l|}
\hline Name of components & \multicolumn{2}{|c|}{ The nature of the land cadastral initiative } \\
\cline { 2 - 3 } & \multicolumn{1}{|c|}{ Current position } \\
\hline $\begin{array}{l}\text { 1. Registration of real } \\
\text { estate }\end{array}$ & $\begin{array}{l}\text { Declarative nature at the initiative of } \\
\text { stakeholders }\end{array}$ & $\begin{array}{l}\text { General character at the initiative of state } \\
\text { (municipal) authorities }\end{array}$ \\
\hline $\begin{array}{l}\text { 2. Cadastral } \\
\text { registration of land }\end{array}$ & $\begin{array}{l}\text { Declarative nature at the initiative of } \\
\text { stakeholders }\end{array}$ & $\begin{array}{l}\text { General character at the initiative of authorities } \\
\text { vested with relevant powers in the land } \\
\text { cadastral sphere }\end{array}$ \\
\hline $\begin{array}{l}\text { 3. Cadastral valuation } \\
\text { of land }\end{array}$ & $\begin{array}{l}\text { General character at the initiative of state } \\
\text { authorities (level of the subject of the } \\
\text { Russian Federation) }\end{array}$ & $\begin{array}{l}\text { Coordination of the results of cadastral } \\
\text { valuation of land with interested municipalities, } \\
\text { taking into account the wishes of } \\
\text { municipalities. }\end{array}$ \\
\hline 4. Soil appraisal & Currently not carried out & $\begin{array}{l}\text { General nature at the initiative of state } \\
\text { authorities in relation to agricultural land (by } \\
\text { licensed budget organizations) }\end{array}$ \\
\hline
\end{tabular}

Source: Based on the results of research by the authors.

As mentioned above, in modern land cadastral activities there are systemic shortcomings that relate to both the structure of the land cadastre and the content of its individual components, and the state of the cadastral system as a whole.

The results of the cadastre create an information base for rational land use. It performs one of the functions of managing the country's land and property complex. This should be taken into account in the process of establishing the most urgent tasks for the development of land cadastral practice, which will ensure the achievement of the country's strategic development goals based on the rational use of its lands (Komov N.V., 2017, 5-11).

Today, as part of cadastral activities, the most developed are registration and accounting functions that allow implementing the fiscal policy of the Russian state. The same purposes are served by land appraisal work, which is carried out with a fixed frequency of 3 to 5 years. The result of the latter is the cadastral value of land, which is the basis for the subsequent establishment of the value of land tax and rent for land.

It should be noted that the appraisal function of the cadastre is significantly weakened by the lack of practice in soil appraisal work (appraisal work in the country has not been carried out for more than a quarter century). This reduces the effectiveness of the cadastre and the value of cadastral data in solving cross-industry issues of land use. The most characteristic case is the assessment of the consequences of the development of road infrastructure. Here, the lack of valuation information significantly reduces the objectivity of determining the damage caused by the removal of land for construction purposes (Bryzhko V.G., Bryzhko I.V., 2019, 19). Soil appraisal data are required in the planning and organization of agricultural production.

Registration of rights to land and other real estate can be considered the initial component of the cadastre. It ensures the stability of the land use system in all areas of the economy, allows you to establish and protect the legal rights to land. Registration is closely related to the accounting function of land cadastral activity, since it is possible to register the right only to the formed land plots recorded in the unified state register of real estate. This functional relationship determines the relationship and mutual conditionality of the problems that occur during the registration of land use and accounting of land property (Varlamov A.A., 2013, 72-86).

The main problem here is not the universal and optional nature of cadastral registration of land plots that has developed in domestic practice. As mentioned above, cadastral registration of land in the country is declarative 
in nature. This means that the state does not actually manage the process of accounting activities, since in practice accounting is carried out on the initiative of individual participants in land relations. Because of this, the legal owners of the plots, the data on which in the real estate register are not updated for any reason, may lose their land rights as a result of illegal actions of third parties who filed an application for registration and registration of the real estate on their behalf.

The land production technology does not contribute to the stability of land use. Registration authorities stopped issuing a paper version of the certificate of state registration of law. All information is stored in electronic form, and an extract from the unified state register of real estate is issued to the subject of law. The absence of a paper version of the main registration document reduces the confidence in the registration process by participants in property relations and makes the cadastre information base vulnerable in case of emergency force majeure situations, as a result of which data from an electronic resource may be lost or distorted. This is a serious drawback of land cadastral practice.

The practice of assessing land property in the country is criticized both by property management bodies and property owners. The dependence of tax and rental payments on the results of cadastral valuation of land causes increased public attention to this process. The main drawback here is the procedure for establishing organizations that carry out appraisal work. These organizations are not always tied to the territory of land appraisal work, which results in land valuation without taking into account local conditions and characteristics. This leads to biased estimates, which in turn causes numerous disputes about the value of the cadastral value of land. Challenging the cadastral value of land occurs everywhere and constantly, affecting all areas of the economy and all regions of the country. This diverts significant resources to unproductive activities and does not contribute to the development of land-use economies (Sevostyanov A.V., 2019, 99-103).

As mentioned above, work on soil appraisal in the country is practically not carried out, which leads to the incompleteness of the land and valuation cadastral information.

These problems do not contribute to the development of land and property relations in the country and require comprehensive resolution. There is a need to create a system of an effective cadastre of real estate with registration of land use, rights and transactions covering all land plots, regardless of their legal affiliation (Volkov S.N., 2015, 6-12).

The authors believe that the formation of land property complexes, their registration and accounting should not be declarative, but mandatory, total. This work requires significant labor and financial costs, but without its implementation it is difficult to create an effective cadastre with clear and transparent procedures that guarantee the establishment and protection of the rights of land owners.

To strengthen the institution of land ownership and increase the level of stability of domestic land ownership, it is advisable to return to the paper form of documents certifying property rights to land plots. Until recently, this procedure in the registration authorities has been quite clearly worked out, so the implementation of this proposal will not cause any difficulties in the land cadastral practice. The issuance of paper documents on the registration of rights to land should be declarative in nature, that is, all cadastral information should be stored electronically in the real estate registry, and upon application by citizens and legal entities, certificates of land rights should be issued.

\section{Conclusions}

The development of land cadastral practice should be affected by the improvement in the quality of valuation work. Land valuation should be carried out on the basis of detailed special surveys, reliable and complete data on the land property market, market relations trends, relevant information on cadastral valuation objects. The 
main task in this direction should be to improve the quality and reliability of land appraisal work. The evaluation quality criterion should be the main one when choosing the organization performing this type of cadastral work.

To more fully take into account the quality of land, especially those engaged in agricultural production, it is necessary to organize work on a full-scale soil survey of the territory with the results of soil assessment. Soil appraisal data should be used in the process of land appraisal actions when obtaining assessment indicators. This will allow a more objective assessment of the land, and the final results of the assessment of land plots by soil fertility and other criteria will be more reliable and accurate. The implementation of this proposal will require the necessary organizational changes in the institution of land cadastral activities in the country and ensure the land valuation process by qualified specialists.

The proposals substantiated by the authors on solving the most important problems of the cadastre make it possible to formulate the priority tasks of the land cadastral practice. The authors relate to these tasks:

- development of the composition and content of land cadastral practice;

- development of the procedure for the formation of real estate, accounting and entering information into a single state register of real estate, registration of land property;

- optimization of land valuation activities, allowing to obtain reliable information about the value of land, including data on soil fertility;

- development of a system for managing land and property relations in the country, land management and land cadastral production;

- staffing of land management and cadastral activities;

- scientific and methodological support of land cadastral practice.

It is advisable to solve the above tasks of the land cadastre simultaneously with the development of other functions of land management and the creation of appropriate legal support. It is especially important to achieve compliance with cadastral practice and land management, land management design (Bryzhko V.G., 2020, 59-66).

The state of land cadastral practice determines the development of economic systems and individual entities, as it provides information on the quantity and quality of real estate used.

Modern land cadastral practice in Russia has systemic shortcomings. The main thing is the discrepancy between the nature, purpose and objectives of the cadastre with the regulations and procedures for its maintenance. The main direction of development of land cadastral practice is the introduction of a universal procedure for land accounting and registration of real estate. To improve the practice of conducting cadastral appraisal work, a process and the results of the appraisal must be agreed with the municipalities, which will help to avoid contesting the cadastral value of land. To assess agricultural land, it is necessary to introduce mandatory soil appraisal work.

Implementation of proposals for the development of land cadastral practice is possible on the basis of solving a number of the most pressing problems. The latter authors include: clarification of the composition and content of cadastral works; development of the procedure for the formation of real estate, its accounting and registration; improving land appraisal practices, including soil appraisal; development of land and property relations, improvement of land management and land cadastral production; staffing of land cadastral practice; scientific and methodological support of land cadastre. 


\section{Bibliographic references}

Bryzhko V.G., Bryzhko I.V. (2019). Comprehensive assessment of the impact of road infrastructure development in rural municipal area (Russia). Revista Espacios. Volume 40 (Issue 37), pages 19. Retrieved from: https://www.revistaespacios.com/a19v40n37/19403719.html

Bryzhko V.G. (2020). Organizational basis of the development of system of land planning design. Revista Espacios. Volume 41 (Issue 22), Pages 59-66. Retrieved from: https://www.revistaespacios.com/a20v41n22/20412205.html

Chengri Ding, Xingshuo Zhao. (2014). Land market, land development and urban spatial structure in Beijing. Land Use Policy, 40, 83-90.

Deininger K., Feder G. (2001). Land institutions and land markets. Handbook of agricultural Economics, 1, Part A, 287-331.

Galchenko S.A. (2017) Voprosy razvitiya sistem kadastrovogo ucheta i registracii nedvizhimosti v Rossii [Issues of development of cadastral registration and real estate registration systems in Russia]. Zemleustrojstvo, kadastr i monitoring zemel', 12, 5-12.

Ivanov N.N. (2019). Sistemnye protivorechiya i problemy kadastrovoj ocenki nedvizhimosti. [Systemic contradictions and problems of cadastral valuation of real estate]. Zemleustrojstvo, kadastr i monitoring zemel', 3, 42-47.

Khlystun V.N. (2018) Strukturny`e izmeneniya v zemel`nom fonde. [Structural changes in the land fund]. Zemleustrojstvo, kadastr i monitoring zemel', 4, 11-18.

Komov N.V. (2017) Zemel 'ny`e resursy` v strategii razvitiya rossijskoj e`konomi-ki [Land resources in the development strategy of the Russian economy]. Zemleustrojstvo, kadastr i monitoring zemel', 1, 5-11.

Rosreestr (2019). State (national) report on the state and use of land in the Russian Federation in 2018 by Rosreestr. 198 p. Retrieved from: https://rosreestr.ru/site/activity/gosudarstvennyy-natsionalnyy-doklado-sostoyanii-i-ispolzovanii-zemel-rossiyskoy-federatsii/

Sevostyanov A.V. (2019). O problemah kadastrovoj ocenki nedvizhimosti/A.V. Sevost'yanov, V.A. Sevost'yanov [On the problems of cadastral valuation of real estate]. Sovremennye problemy upravleniya proektami v investicionno-stroitel'noj sfere i prirodopol'zovanii: materialy mezhdunarodnoj nauchno-prakticheskoj konferencii, 99-103.

Varlamov A.A. (2013). Problemy razvitiya kadastrovyh sistem v Rossijskoj Federacii [Problems of the development of cadastral systems in the Russian Federation]. Imushchestvennye otnosheniya v Rossijskoj Federacii, 11, 72-86.

Volkov S.N. (2015) Kak organizovat' effektivnoe upravlenie zemel'nymi resursami v Rossijskoj Federacii [How to organize effective land management in the Russian Federation]. Zemleustrojstvo, kadastr i monitoring zemel', 9, 6-12.

Esta obra está bajo una Licencia Creative Commons Attribución-NoCommercial 4.0 International

\section{(cc) $\mathbf{B Y}-\mathrm{NC}$}

